\title{
EVALUATION OF REACTION KINETICS FOR
}

\section{GAS-POWDER SYSTEMS}

Jerry L. Stakebake

G. Edward Bixby 


\section{DISCLAIMER}

This report was prepared as an account of work sponsored by an agency of the United States Government. Neither the United States Government nor any agency Thereof, nor any of their employees, makes any warranty, express or implied, or assumes any legal liability or responsibility for the accuracy, completeness, or usefulness of any information, apparatus, product, or process disclosed, or represents that its use would not infringe privately owned rights. Reference herein to any specific commercial product, process, or service by trade name, trademark, manufacturer, or otherwise does not necessarily constitute or imply its endorsement, recommendation, or favoring by the United States Government or any agency thereof. The views and opinions of authors expressed herein do not necessarily state or reflect those of the United States Government or any agency thereof. 


\section{DISCLAIMER}

Portions of this document may be illegible in electronic image products. Images are produced from the best available original document. 


\section{LEGAL NOTICE}

This report was prepared as an account of work sponsored by the United States Government. Neither the United States nor the Department of Energy, nor any of their employees, nor any of their contractors, subcontractors, or their employees, makes any warranty, expressed or implied, or assumes any legal liability or responsibility for the accuracy, completenesss or usefulness of any information, apparatus, product or process disclosed, or represents that its use would not infringe privately owned rights.

Printed in the United States of America

Available from the

National Technical Intormatiun Service

U. S. Department of Commerce

Springfield, Virginia 22161

Price: Printed Copy $\$ 4.50$ Microfiche $\$ 3.00$

Price Is Subject to Change Without Notice 
Printed

June 25, 1979
RFP-2849

UC-4 CHEMISTRY.

TID-4500-R66

EVALUATION OF REACTION KINETICS FOR

\section{GAS-POWDER SYSTEMS}

Jerry L. Stakebake

G. Edward Bixby

SUBJECT DESCRIPTORS

Kinetics

Powder

Gas

Uranium Hydriding

ROCKWELL INTERNATIONAL ENERGY SYSTEMS GROUP ROCKY FLATS PLANT

P.O. BOX 464

GOLOEN, COLORADO 80401

Prepared under Contract DE-ACO4-76DPO3533

for the

Albuquerque Operations Office

U.S. Department of Energy 


\section{CONTENT S}

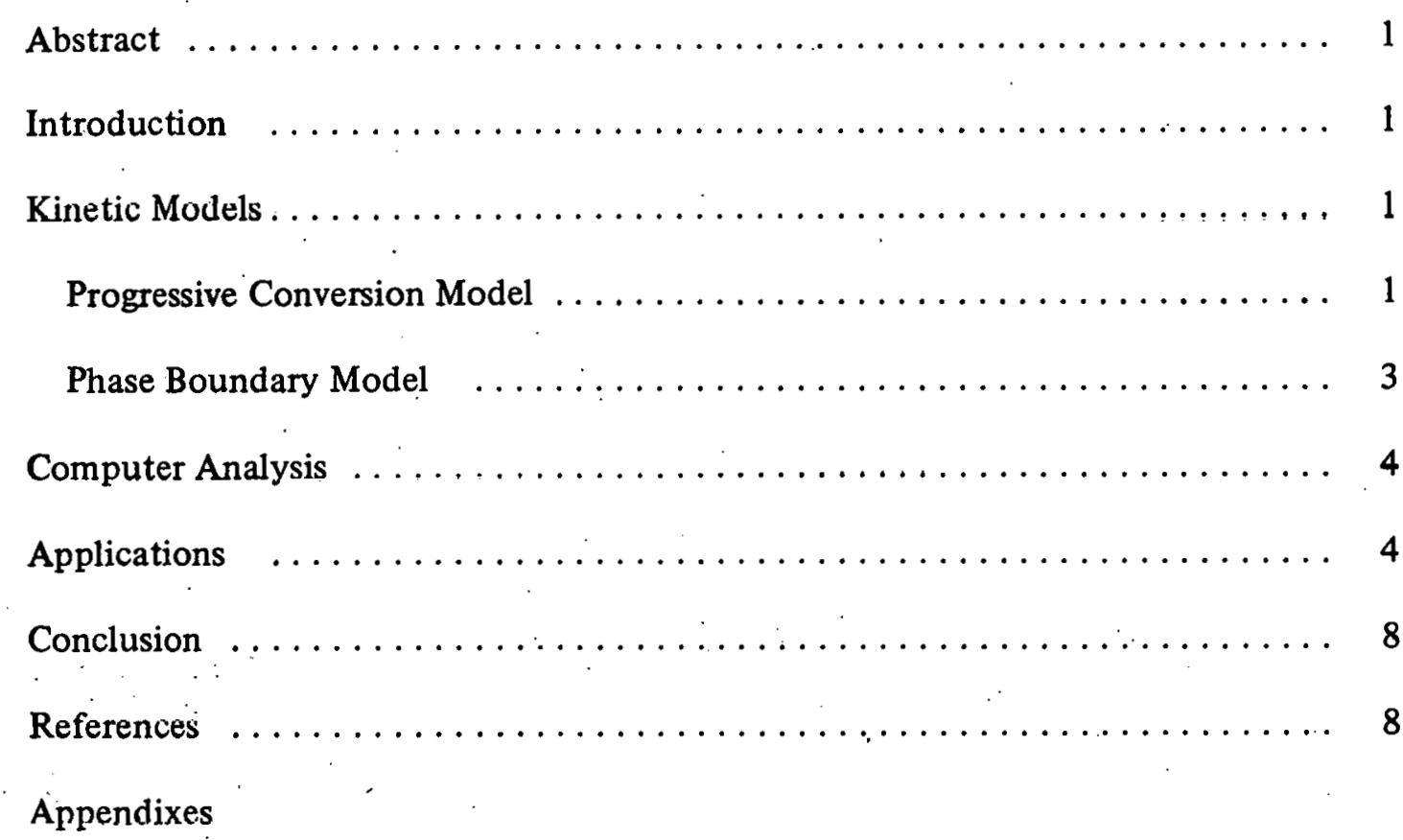

A. Computer Program for Equations 5 and $7 \ldots \ldots \ldots \ldots \ldots$

B. Computer Program for the Jander Equation (Equation 13) $\ldots \ldots \ldots \ldots 19$

C. Computer Program for the Phase Boundary Model (Equation 16) . . . . . 21 


\title{
EVALUATION OF REACTION KINETICS FOR
} GAS-POWDER SYSTEMS

\author{
Jerry L. Stakebake and G. Edward Bixby
}

\begin{abstract}
Kinetic models for the reaction between a gas and powder are presented and discussed. Rates from the "progressive conversion" model are dependent on the amount of material present. This model is described by an equation that yields both the rate constant and the reaction order. The "phase boundary" model produces rates for topochemical reactions which are dependent on the powder surface area. Applications of these models to uranium powder hydriding are liscussed. Computer programs for analyzing data also are included.
\end{abstract}

\section{INTRODUCTION}

Experimental programs are underway to evaluate the reaction between gases and various powders. The primary interest in these programs is the rate of reaction between the gas and the solid powder. Evaluation of reaction kinetics involves consideration of two fundamental processes: (1) the chemical reaction itself and (2) transport of the gas to the reaction zone. Both of these processes may involve several individual steps that may be rate controlling for the entire reaction. This report evaluates some of the basic fundamentals of powder reaction kinetics; it also illustrates their application to the hydriding of uranium powder.

\section{KINETIC MODELS}

Chemical reactions result from atomic and molecular collisions. If the reactants are mixed on an atomic level, the reaction kinetics can be described mathematically with equations involving only time and concentration. This results in what will be termed the "progressive conversion" model.

Often, however, gases and solids are not mixed on the atomic level and the gas must diffuse or penetrate to the phase boundary before reacting.
If the gas diffuses very slowly into the solid, the reaction takes place at a gas-solid interface, which results in a "phase boundary" model.

Both the "progressive conversion" and "phase boundary" models may include several different steps in the reaction. The following steps are possible:

1. Diffusion of the gaseous reactant to the solid surface.

2. Adsorption of the gaseous reactant.

3. Diffusion of the gas either into the bulk or to the solid reactant-gas interface.

4. Reaction of the gas with the solid.

5. Diffusion of any gaseous product to the solid surface.

6. Desorption of the gaseous reaction product.

At times some of these steps do not exist. The resistance of each step to the progress of the reaction varies. The step with the highest resistance is said to be rate controlling.

\section{Progressive Conversion Model}

The basic assumption of this model is that the reacting gas diffuses rapidly through the solid particle so that the reaction takes place uniformly throughout the particle. This type of behavior is illustrated in Figure 1 for the hydriding of a metal particle. The reaction rate is then dependent only on the concentration of the metal available-providing that the availability of the reacting gas is not limited by either the adsorption or diffusion steps.

Fvaluation of the "progressive conversion" model involves expressions that relate reactant concentration to time. ${ }^{1}$ If $M_{0}$ is the initial concentration of 


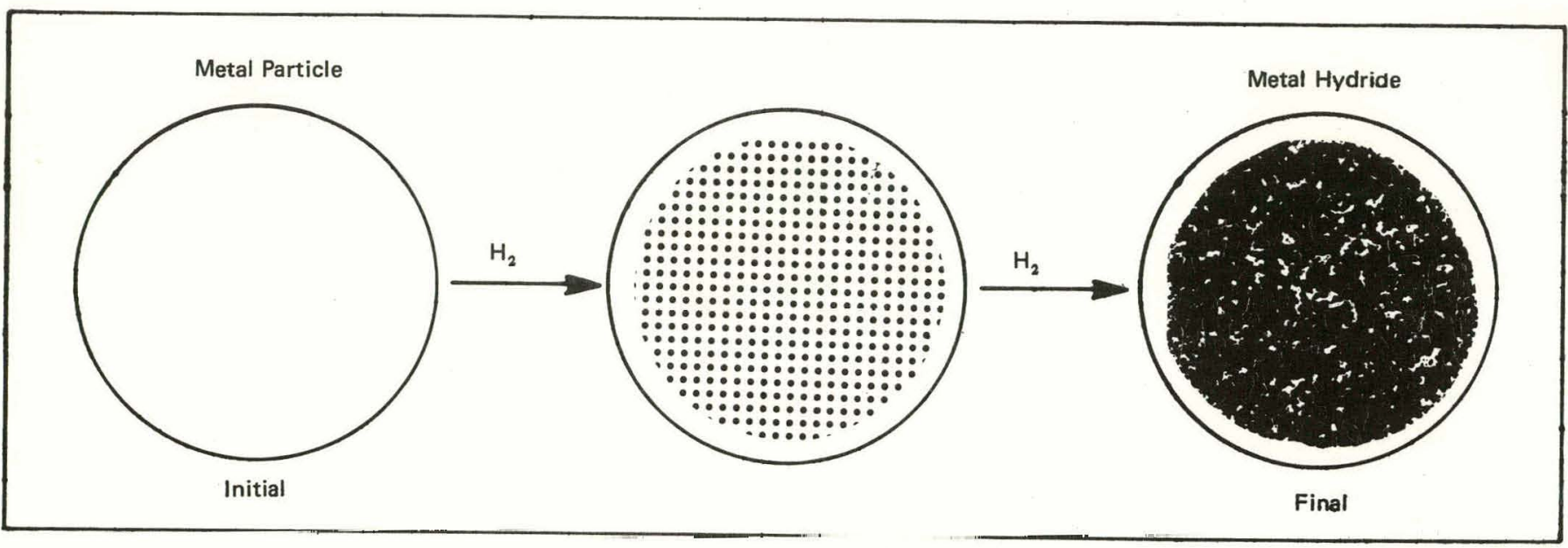

FIGURE 1. Progrcssive Cónvensiun Mudel

the solid and $\mathrm{M}_{\mathrm{t}}$ is the amount reacted at time $\mathrm{t}$, then the amount left unreacted is $\mathrm{M}_{0}-\mathrm{M}_{\mathrm{t}}$. The rate of disappearance of the solid is

$$
\frac{-d\left(M_{0}-M_{t}\right)}{d t}=\frac{d M_{t}}{d t}=K\left(M_{0}-M_{t}\right)^{n}
$$

where $\mathrm{K}=$ rate constant and $\mathrm{n}=$ order of reaction.

If this is integrated with the boundary condition that $\mathrm{M}_{\mathrm{t}}=0$ when $\mathrm{t}=0$, and $\mathrm{n} \neq 1$, then

$$
K=\frac{1}{t(n-1)}\left[\frac{1}{\left(M_{0}-M_{t}\right)^{n-1}}-\frac{1}{M_{0}^{n-1}}\right]
$$

Since the parameter being measured is $\mathrm{W}_{\mathrm{t}}$, the amount of gas being reacted at time $t$, and $W_{m}$ is the maximum amount of gas reacted, then

$$
\mathrm{M}_{\mathrm{t}}=\frac{\mathrm{W}_{\mathrm{t}}}{\mathrm{W}_{\mathrm{m}}} \mathrm{M}_{0}
$$

The general solution to Equation 2 becomes

$$
K=\frac{1}{t(n-1)}\left[\frac{1}{\left(M_{0}-\frac{W_{t} M_{0}}{W_{m}}\right)^{n-1}}-\frac{1}{M_{0}^{n-1}}\right]
$$

Rearranging Equation 4 results in

$$
\left(M_{0}-\frac{W_{t} M_{0}}{W_{m}}\right)^{n-1}=K(n-1) t+M_{0}^{1-n}
$$

or

$$
M_{0}^{1-n}\left(1-\frac{W_{t}}{W_{m}}\right)^{1-n}=K(n-1) t+M_{0}^{1-n}
$$

or

$$
\left(1-\frac{W_{t}}{W_{m}}\right)=\left[K(n-1) M_{0}{ }^{n-1} t+1\right]^{1 /(1-n)}
$$

By further rearranging, the working equation becomes

$$
\mathrm{W}_{\mathrm{t}}=\mathrm{W}_{\mathrm{m}}\left[1-\left(1+\mathrm{K}(\mathrm{n}-1) \mathrm{M}_{0}{ }^{\mathrm{n}-1} \mathrm{t}\right) 1 /(1-\mathrm{n})\right]
$$

when $\mathrm{t}<\mathrm{M}_{0} 1-\mathrm{n} / \mathrm{K}(1-\mathrm{n})$ and $\mathrm{n}=1$.

Where $\mathrm{t} \geqslant \mathrm{M}_{0} 1-\mathrm{n} / \mathrm{K}(1-\mathrm{n})$ and $0<\mathrm{n}<1$, then $\mathrm{W}_{\mathrm{t}}=\mathrm{W}_{\mathrm{m}}$.

For Equation 5,

$\mathrm{n}=$ order of the reaction.

$\mathrm{W}_{\mathrm{t}}=$ weight gain at time $\mathrm{t}$, in milligrams per gram.

$\mathrm{M}_{0}=$ milligrams of atoms of solid material at $\mathrm{t}=0$.

$\mathrm{W}_{\mathrm{m}}=$ weight gain at $\mathrm{t}=\propto$, in milligrams per gram.

$\mathrm{K}=$ rate constant.

In the special case where $\mathrm{n}=1$ for a 1 st-order reaction, Equation 4 becomes

$$
\mathrm{K}=\frac{1}{\mathrm{t}} \ln \frac{\mathrm{M}_{0}}{\mathrm{M}_{0}-\mathrm{M}_{\mathrm{t}}}
$$




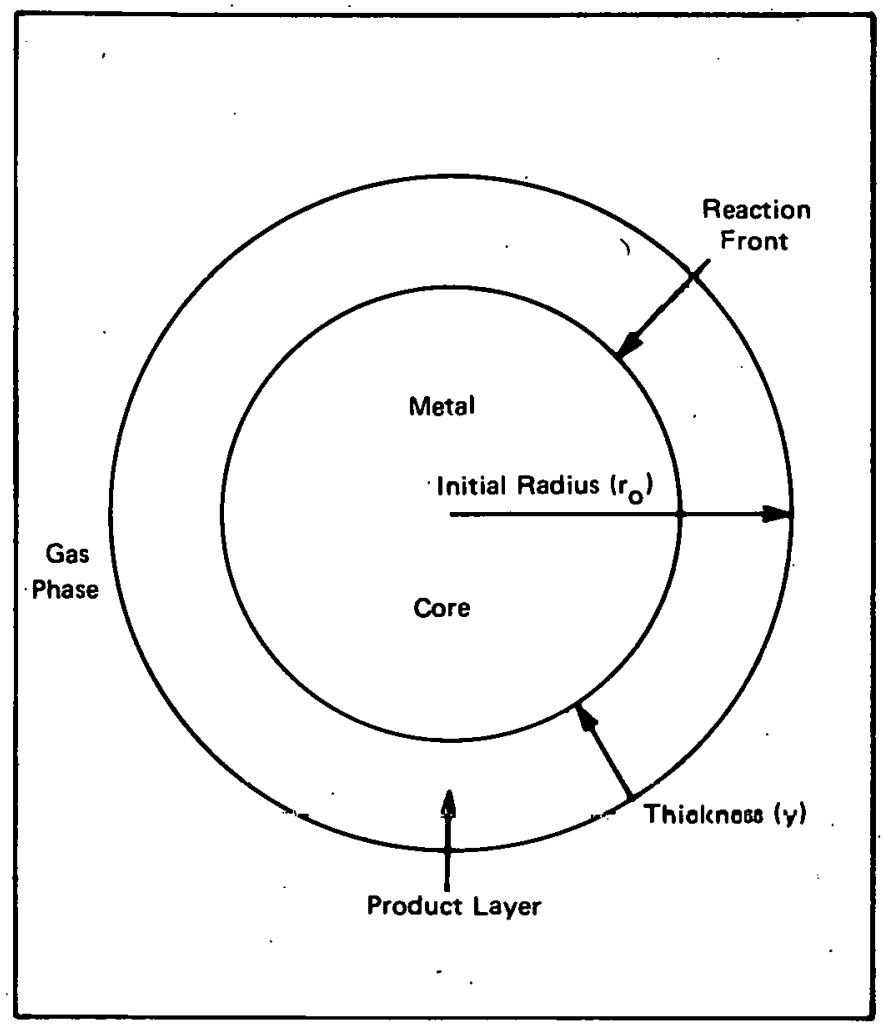

FIGURE 2. Phase Boundary Model

By substitution of Equation 3 into Equation 6

$$
\mathrm{w}_{\mathrm{t}}=\mathrm{w}_{\mathrm{m}}\left(1-\mathrm{e}^{-\mathrm{Kt}}\right)
$$

\section{Phase Boundary Model}

The reaction predicted by this model occurs at the gas-solid interface and is illustrated in Figure 2. In this case the reaction front moves toward the center of the solid particle. During the reaction, the total particle size may increase, decrease, or remain the same depending on the molar volume of the reaction product. The core, however, remains unreacted.

The product layer may be porous with no protective qualities or it may be dense and thus present a diffusion barrier between the solid and gas.

This model can be evaluated by assuming the reaction produces a product layer of thickness, $y$, which reduces the initial radius, $\mathbf{r}_{0}$; of each spherical particle. (See Figure 2.) The volume of unreacted material at time $t$ becomes

$$
V_{t}=\frac{4}{3} \Pi\left(r_{0}-y\right)^{3}
$$

If $\alpha$ is the fraction of the solid material reacted at time $t$, the volume of material unreacted becomes

$$
V=\frac{4}{3} \Pi r_{0}^{3}(1-\alpha)
$$

By equating Equations 8 and 9, the thickness of the product layer becomes

$$
y=r_{0}\left[1-(1-\alpha)^{1 / 3}\right]
$$

If the reaction produces a product having a molar volume greater than that of the solid reactant, a protective, non-porous layer is formed and the reaction becomes diffusion controlled. This results in a parabolic rate expression for the growth of the product layer, which is given by

$$
y^{2}=k_{p} t
$$

where $\mathrm{k}_{\mathrm{p}}$ is the parabolic rate constant.

Combining Equation 11 with Equation 10 produces the Jander ${ }^{2}$ equation

$$
y^{2}=r_{0}^{2}\left[1-(1-\alpha)^{1 / 3}\right]^{2}=k_{p} t
$$

or

$$
\left[1-(1-\alpha)^{1 / 3}\right]^{2}=\frac{\mathrm{k}_{\mathrm{p}} \mathrm{t}}{\mathrm{r}_{0}^{2}}=\mathrm{k}_{\mathrm{j}} \mathrm{t}
$$

where $\mathrm{k}_{\mathrm{j}}$ is the observed Jander rate constant.

If the product layer is porous, the phase boundary reaction results in a linear growth of the product layer. Thus

$$
\frac{d y}{d t}=k \text { or } y=k t
$$

where $\mathrm{k}$ is the linear rate constant.

Combining Equations 10 and 14 yields

$$
y=r_{0}\left[1-(1-\alpha)^{1 / 3}\right]=k t
$$

or 


$$
1-(1-\alpha)^{1 / 3}=\frac{\mathrm{k}_{\mathrm{t}}}{\mathrm{r}_{0}}=\mathrm{k}_{\mathrm{L}} \mathrm{t}
$$

where $k_{\mathrm{L}}$ is the experimentally determined phase boundary rate. Equation 16 has been used by Muromura and $\mathrm{Ouchi}^{3}$ to evaluate the nitrogenation of plutonium hydride.

Alternative Derivation of the Phase Boundary Model

When the gas-solid reaction is phase-boundary controlled, the reaction rate is proportional to the surface area of the unreacted material. Thus

$$
\frac{d v_{t}}{d t}=k_{A} S_{t}
$$

where $V_{t}$ is the volume at time $t, S_{t}$ is the surface area, and $k_{A}$ is the surface area dependent rate constant. The unreacted fraction is $(1-\alpha)$ where $\alpha$ is the fraction reacted, that is,

$$
(1-\alpha)=\frac{V_{t}}{V_{0}}=\frac{r_{t}^{3}}{r_{0}^{3}}
$$

or

$$
r_{t}^{2}=r_{0}^{2}(1-\alpha)^{2 / 3}
$$

where $V_{0}=$ initial volume and $r_{t}=$ radius at time $t$.

The rate of change of the unreacted fraction becomes

$$
\frac{-d(1-\alpha)}{d t}=\frac{d\left(V_{t} / V_{0}\right)}{d t}=\frac{V_{0} \frac{d V_{t}}{d t}}{V_{0}^{2}}=\frac{k_{A} S_{t}}{V_{0}}
$$

then

$$
\frac{\mathrm{d} \alpha}{\mathrm{dt}}=\frac{\mathrm{k}_{\mathrm{A}} \mathrm{S}_{\mathrm{t}}}{\mathrm{V}_{0}}=\frac{\mathrm{k}_{\mathrm{A}} 4 \Pi_{\mathrm{t}}^{2}}{\frac{4}{3} \Pi \mathrm{r}_{0}^{3}}=\frac{3 \mathrm{k}_{\mathrm{A}} \mathrm{r}_{\mathrm{t}}^{2}}{\mathrm{r}_{0}^{3}}
$$

Substitution of Equation 19 into Equation 21 results in

$$
\frac{\mathrm{d} \alpha}{\mathrm{dt}}=\frac{3 \mathrm{k}_{\mathrm{A}} \mathrm{r}_{0}^{2}(1-\alpha)^{2 / 3}}{r_{0}^{3}}=\frac{3 \mathrm{k}_{\mathrm{A}}}{\mathrm{r}_{0}}(1-\alpha)^{2 / 3}
$$

Equation 22 shows that the maximum reaction order for a topochemical reaction is $2 / 3$.

Integration of Equation 22, assuming that $\alpha=0$ when $t=0$, results in the expression

$$
1-(1-\alpha)^{1 / 3}=\frac{\mathrm{k}_{\mathrm{A}} \mathrm{t}}{\mathrm{r}_{0}}
$$

If $\mathrm{k}_{\mathrm{A}} / \mathrm{r}_{0}=\mathrm{k}_{\mathrm{L}}=$ the linear phase boundary rate constant, then Equation 23 equals Equation 16.

\section{COMPUTER ANALYSIS}

Analysis of data, using the different reaction modele; was dono by computor or calculator. A time-shared computer was used for the "progressive conversion" model. A copy of the Fortran program for Equations 5 and 7 are included as Appendix A. Copies of the program on paper tape in addition to instructions may be obtained from the authors.

Data analysis according to the "phase boundary" model was performed on a Hewlett Packard Model 9825A calculator. The programs used for the Jander equation and the general phase-boundary reaction equation arc included in Appendixes B and $C$ respectively. Questions regarding data processing should be directed to the authors.

\section{APPLICATIONS}

To illustrate the application of the kinetic models to real reaction systems, data from the hydriding of uranium powder will be evaluated. Uranium powder samples were prepared by a series of hydriding and dehydriding cycles. Conditions for the hydriding runs being reported were $100^{\circ} \mathrm{C}$ and either $13.3 \mathrm{kPa}$ or $26.6 \mathrm{kPa}$ hydrogen pressure. Figure 3 shows a hydriding run at $100^{\circ} \mathrm{C}$ and 13.3 $\mathrm{kPa}$ hydrogen that was analyzed using the "progressive conversion" model and Equation 5. This model describes the process very well and shows the reaction to be $2 / 3$-order. The correlation coefficient obtained using Equation 5 was 0.9983.

Since the order of the run in Figure 3 was $2 / 3$, it might be expected that a topochemical reaction is 
FIGURE 3. Application of the General Rate Equation (Equation 5) to Uranium Hydriding at $100{ }^{\circ} \mathrm{C}$ in $13.3 \mathrm{kPa}$ Hydrogen. The maximum gas reacted was $12.2 \mathrm{mg} / \mathrm{g}$, rate constant was 2.387 , and 0.65 was the order of reaction.

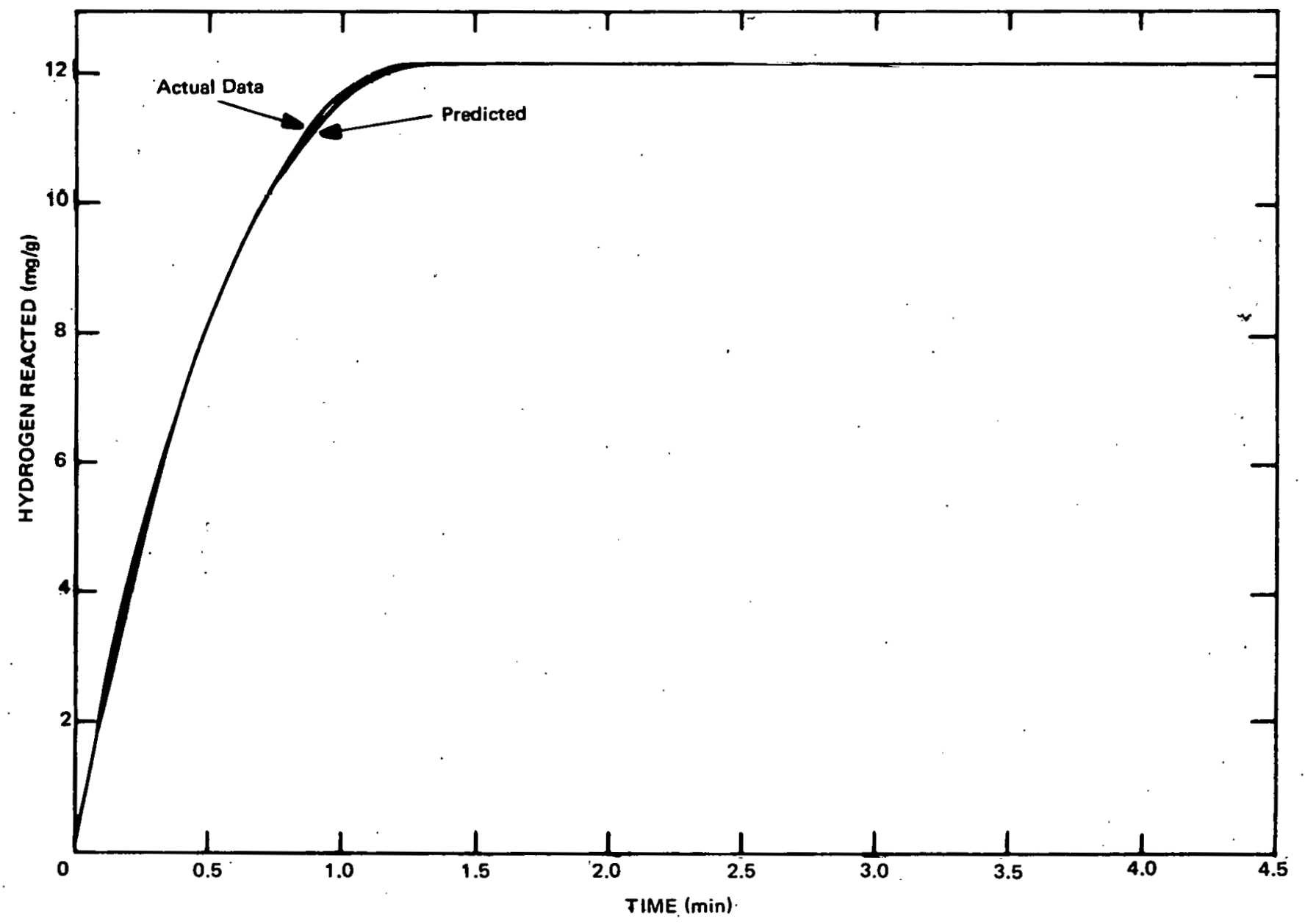


FIGURE 4. Application of Equation 16 to the 1st-Order Reaction of Run 10 in $26.6 \mathrm{kPa}$ Hydrogen at $97^{\circ} \mathrm{C}$ and the 2/3-Order Reaction of Run 2 in 13.3 $\mathrm{kPa}$ of Hydrogen at $100{ }^{\circ} \mathrm{C}$. The solid lines are the predicted fit. In Run 2, the phase boundary rate was $0.652 \mathrm{~min}^{-1}$; it was $0.827 \mathrm{~min}^{-1}$ in Run 10 .

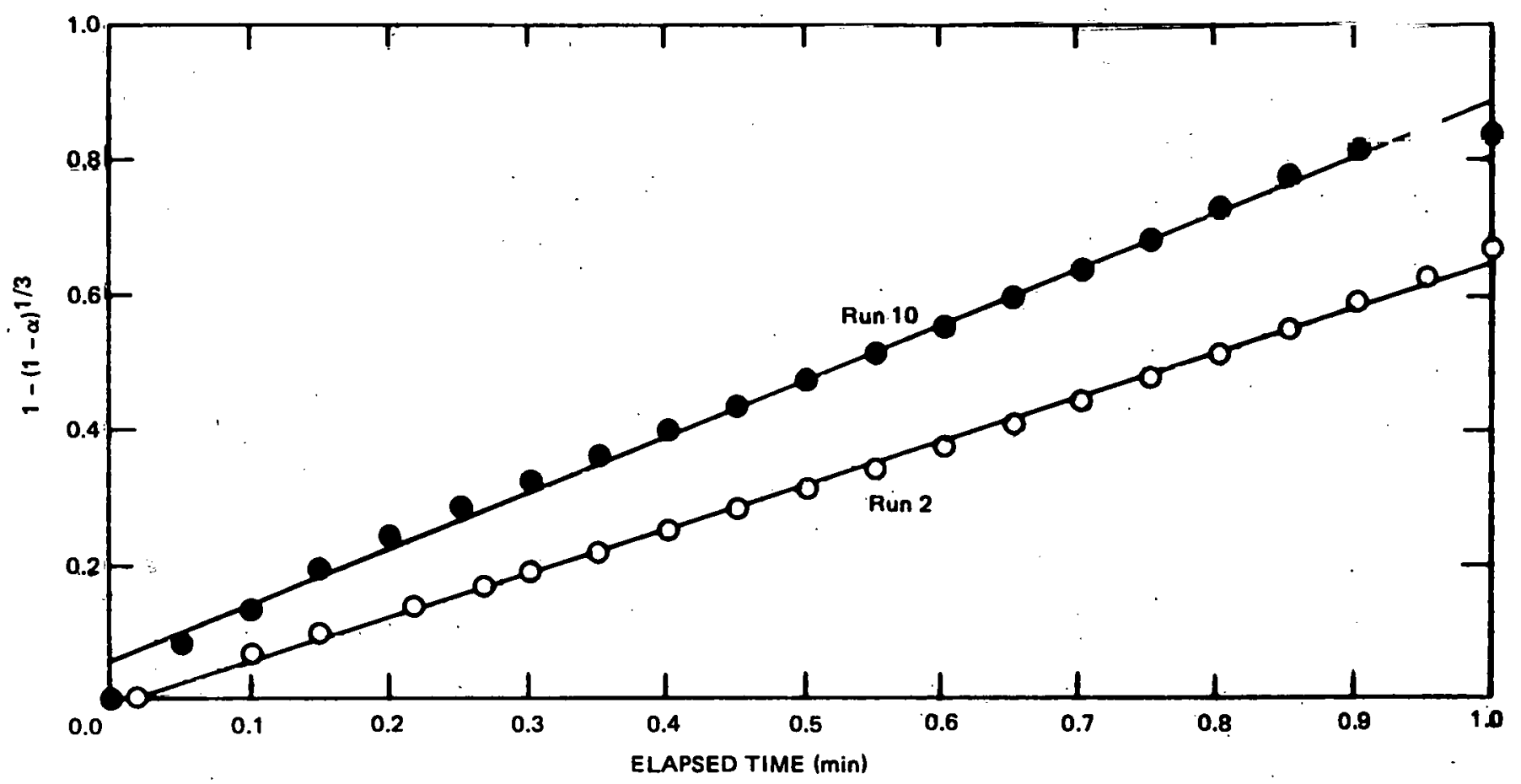




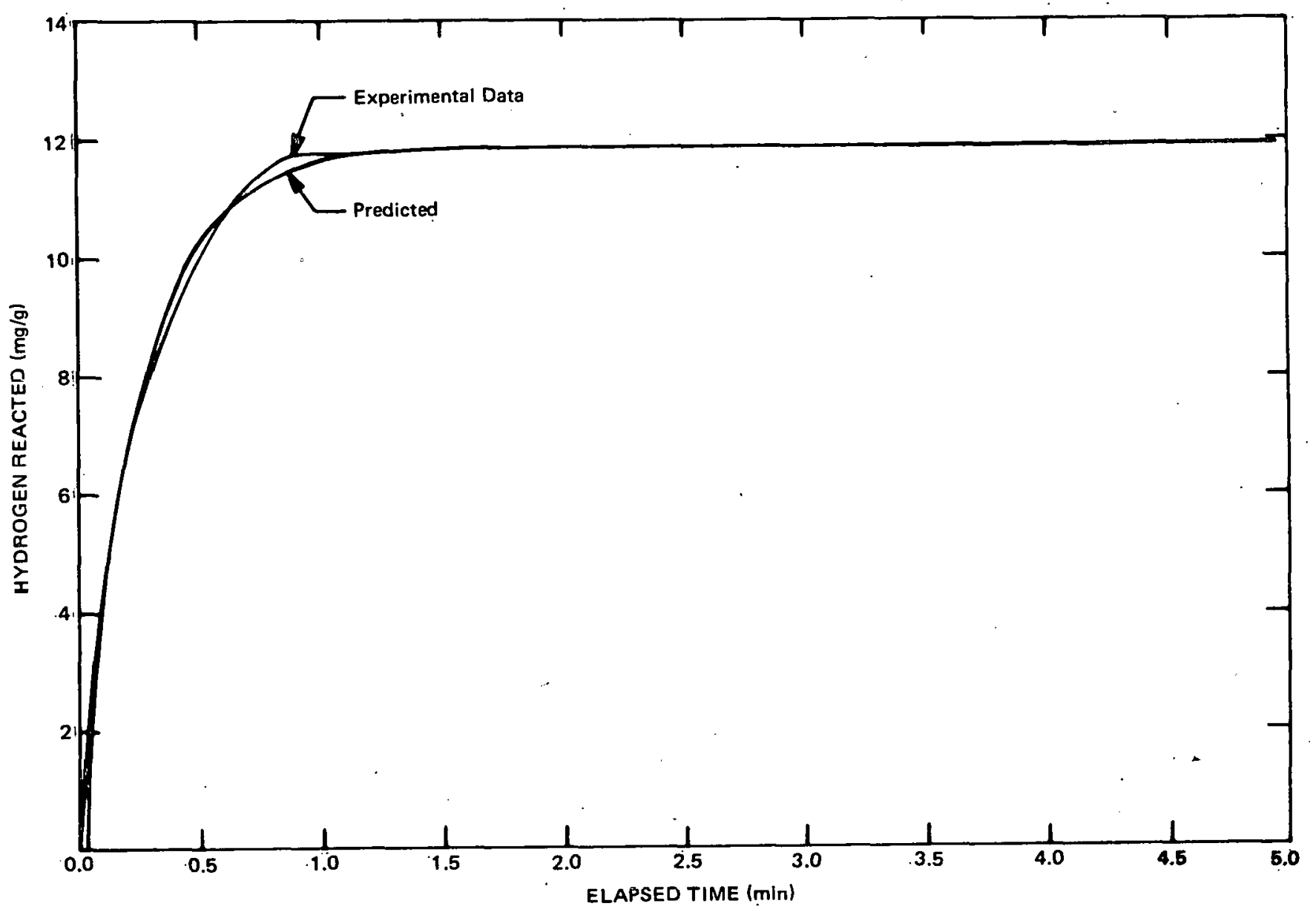

FIGURE 5. Evaluation of Hydriding Data Obtained at $97^{\circ} \mathrm{C}$ in 26.6

$\mathrm{kPa}$ Hydrogen Using Equations 5 and 7 for a 1st-Order Reaction

taking place. In this case, the experimental data might better be fit by the "phase boundary model." Figure 4, Run 2, shows the fit of Equation 16 to these data. The fit appears good for about $95 \%$. of the reaction. The correlation coefficient obtained in this case was 0.9989 . It should be noted that Equation 16 does not accurately fit the data from the first and last part of the run.

Figure 5 shows an experimental run at $97^{\circ} \mathrm{C}$ in $26.6 \mathrm{kPa}$ hydrogen. The experimental data were analyzed using Equation 5, which showed the reaction to be 1 st-order, and Equation 7 . The correlation coefficient obtained using both of these equations was 0.9984 . Since this experimental . run was shown to be 1st-order, the "progressive conversion" model may offer a better representation than the "phase boundary" model. Figure 4, Run 10 , shows the evaluation using Equation 16. for the "phase boundary" model. Although the model appears to fit well overall, there was some deviation at the beginning and end of the run. The correlation coefficient was 0.9968 .

Use of the Jander equation (Equation 13) to explain the hydriding of uranium powder is not valid, as can be seen in Figure 6. This indicates that gas transport is not the rate-limiting step in this reaction. 


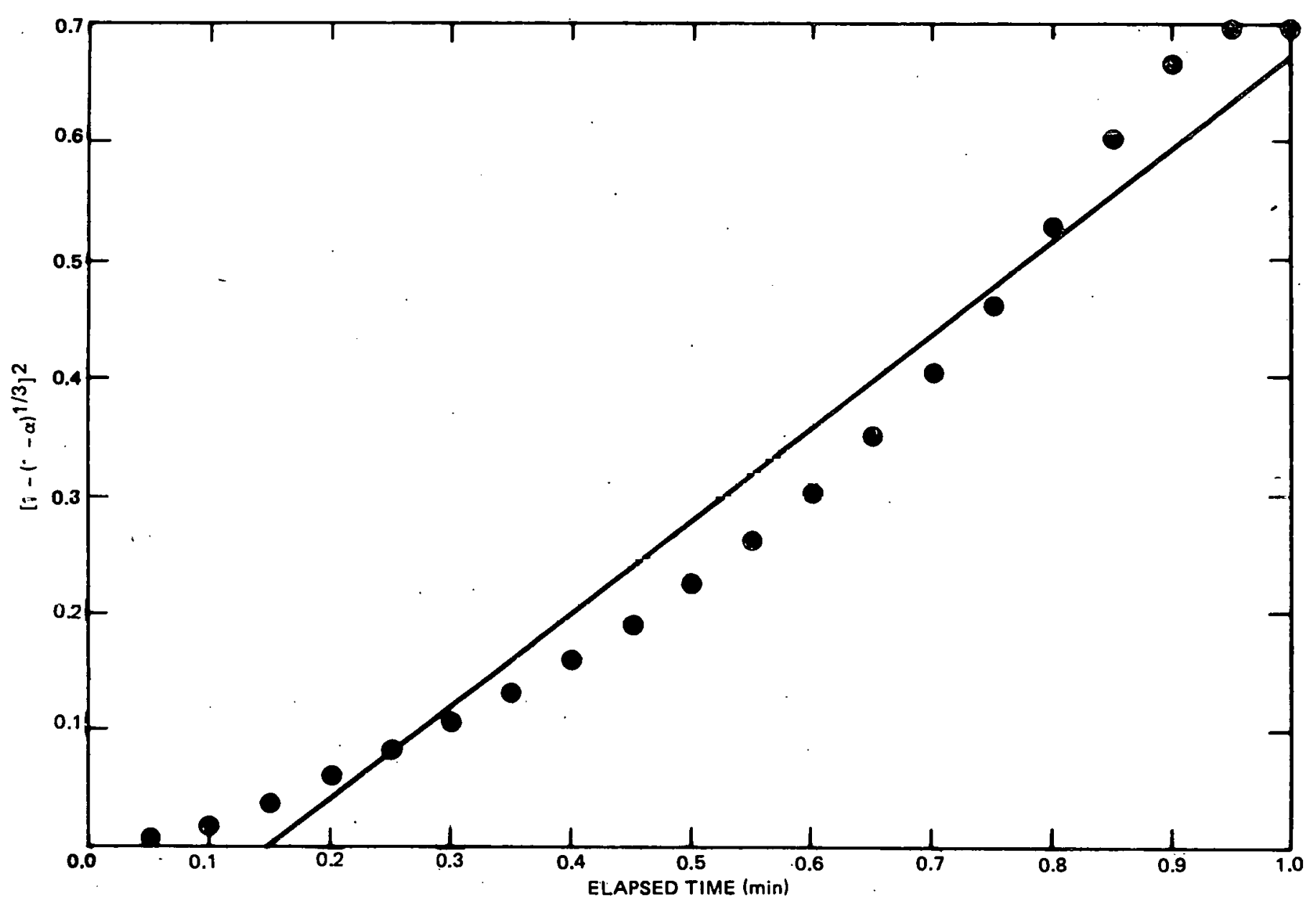

FIGURE 6. Application of the Jander Equation to the Analysis of Uranium Powder Hydriding in $26.6 \mathrm{kPa}$ Hydrogen at $91^{\circ} \mathrm{C}$

\section{CONCLUSION}

Two models are presented for the reaction of gases with powders. The "progressive conversion" model is dependent on the amount or concentration of the solid powder. The "phase boundary" model is related to the constant growth of the product layer and to the surface area of the unreacted powder. If the product layer becomes a barrier to the reacting gas, then the rate is controlled by the diffusion process, and the Jander equation applies.

In the special application of these models to the hydriding of uranium powder, both the "progressive conversion" and "phase boundary" models appear to be equally applicable. This is undoubtedly true because of the small particle size being used.

\section{REFERENCES}

1. K. J. Laidler. Chemical Kinetics. McGrawHill Book Co., New York. 1965.

2. S. F. Hulbert. J. Brit. Ceram. Soc., Vol. 6, p. 11. (1969).

3. T. Muromura and K. Ouchi. J. Inorg. Nucl. Chem., Vol. 36, p. 2525. (1974). 
RFP-2849

\section{APPENDIX A}

Computer Program for Equations 5 and 7

00010 PROGRAM GEBNL (INPUT $=65 / 80$, OUTPUT $=65, \mathrm{TAPE} 1=65, \mathrm{TAPE} 7=65, \mathrm{TAPE} 5=$ INPUT)

00020 DIMENSION SS(99), BK( 5$), Z(4,99), \operatorname{BDEL}(4), N Z(4)$

00030 COMMON PAR $(800,5), X T R A N(5,800)$

00040 DIMENSION $\operatorname{SAUE}(5,5), X \operatorname{SAVE}(5,5)$

00050 DIMENSION XPROD $(6,6), D E L(800), T(5)$

00060 COMMON/GENTNL/X $(800,5), Y X P(800), J, N, Z, I T E R, B D E L, N O P T$,

$00070+N O P T 2, N Z, N N L, I N L, N P, X P Y(5), Y T H(800), N O U T$

0008045 FORMATC/. ITERATION SUIS OF SQUARES

$00.090+$-NL PARAMETER DELTA $/ 2$

0010046 FORMAT (4X,I 2, 6X, 1PE15.8,5X,1PE12.5, 2X, 1PE10.3)

00110 . INTEGER B

0012051 FORMAT(/1X'THE T STATISTICS AND 68 C.L. DELTAS ARE*/)

0013052 FORMAT(/IX THE STANDARD ERROR IS (1PE15.8)

0014049 FORMAT(/IX THE CORRELATION COEFFICIENT IS ,F6.4)

0015053 FORMAT(/1X'THE SUM OF THE SQUARED ERRORS IS 1 PE15.8)

0016054 FORMAT $\left(/ 1 X^{\circ}\right.$ I MEASURED VALUE PREDICTED VALUE ERROR\%

0017055 PORMAT $/ 15 \%$ - REGRESSION ANALYSI $S \% /$ )

0018059 FORMAT( $/ 1 X^{\circ}$ THE REGRESSION. EQUATION PARAMETERS ARE* $)$

0019070 FORIAT $(1 X, 2 H A(, I 2,2 H)=, 1$ PE 15.8)

0020071 FORHAT $(1 \mathrm{X}, 2 \mathrm{HT}(, 12,2 \mathrm{H})=, 1 \mathrm{PE}, 2,2 \mathrm{~K}, 4 \mathrm{HDEL}(, \mathrm{I} 2,2 \mathrm{H})=, 2 \mathrm{X}$,

$00210+1 \mathrm{PE} 10.3)$

0022080 FOPMAT(I $4,2 X, 1$ PE 15.8, 3X, 1PE15.8,3\%, 1PE10.3)

0023087 FORIAT(/ MATRIX IS SINGULAR OR EPS IS TOO LARGE')

0024088 FOPMAT( $/$ " INVERSE WAS NOT OBTAINED')

0025089 FORMATC/ $/$ INSUFFICIENT NUMBER OF DATA POINTS*,

$002600^{\circ}$ FOR THIS ORDER FIT')

0027044 FOPHATC/1" \# SS NLI NL2,

$00280+0^{\circ} \quad$ NL3 NL 3 /22X, DEL1, $9 \%$,

$00290+\cdot D E L 2 \cdot, 9 X, \cdot D E L 3 \cdot, 9 X, \cdot D E L 4 \cdot /)$

0030043 FORMAT $(1 X, 12,5(2 X, 1 \mathrm{PE} 11.4))$

0031042 FOPMAT( $\left.{ }^{\circ} N\left(\varphi, I 1,{ }^{\prime}\right)=?, 1 P E 12+5\right)$

0032041 FORMAT $(/$ THE NON-LINEAR PARAMETERS ARE*/)

0033040 FORNIAT $(18 X, 4(1 P E 11,4,2 X))$

00340 RELIND 1

00350 PFINT 55

00360 I TER $=1$

00370 ILAST $=0$

00380 NEXPT $=2$

0039016 CALL GENTNL(PAR)

00400 DO $400 \quad I=1, \mathrm{~N}$

00410 DO $400 \quad K=1, \mathrm{~J}$

$00420400 \quad X$ TRAN $(K, I)=X(I, K)$

00430 DO $510 \quad I=1, \mathrm{~J}$

00440 DO $510 \mathrm{~K}=1, \mathrm{~J}$

$00450 \times P R O D(I, K)=0$

00460 DO $510 \mathrm{M}=1, \mathrm{~N}$

00470510 XFROD $(I, K)=X P R O D(I, K)+X T R A N(I, M) * X(M, K)$

00480 DO $519 \quad 1=1, \mathrm{~J}$

00490 DO $519 \quad M=1, \mathrm{~J}$

$00500.519 \operatorname{SAVE}(I, M)=X P F O D(I, M)$

$00510 \mathrm{~B}=\mathrm{J}$ 
RFP-2849

APPENDIX A (continued)

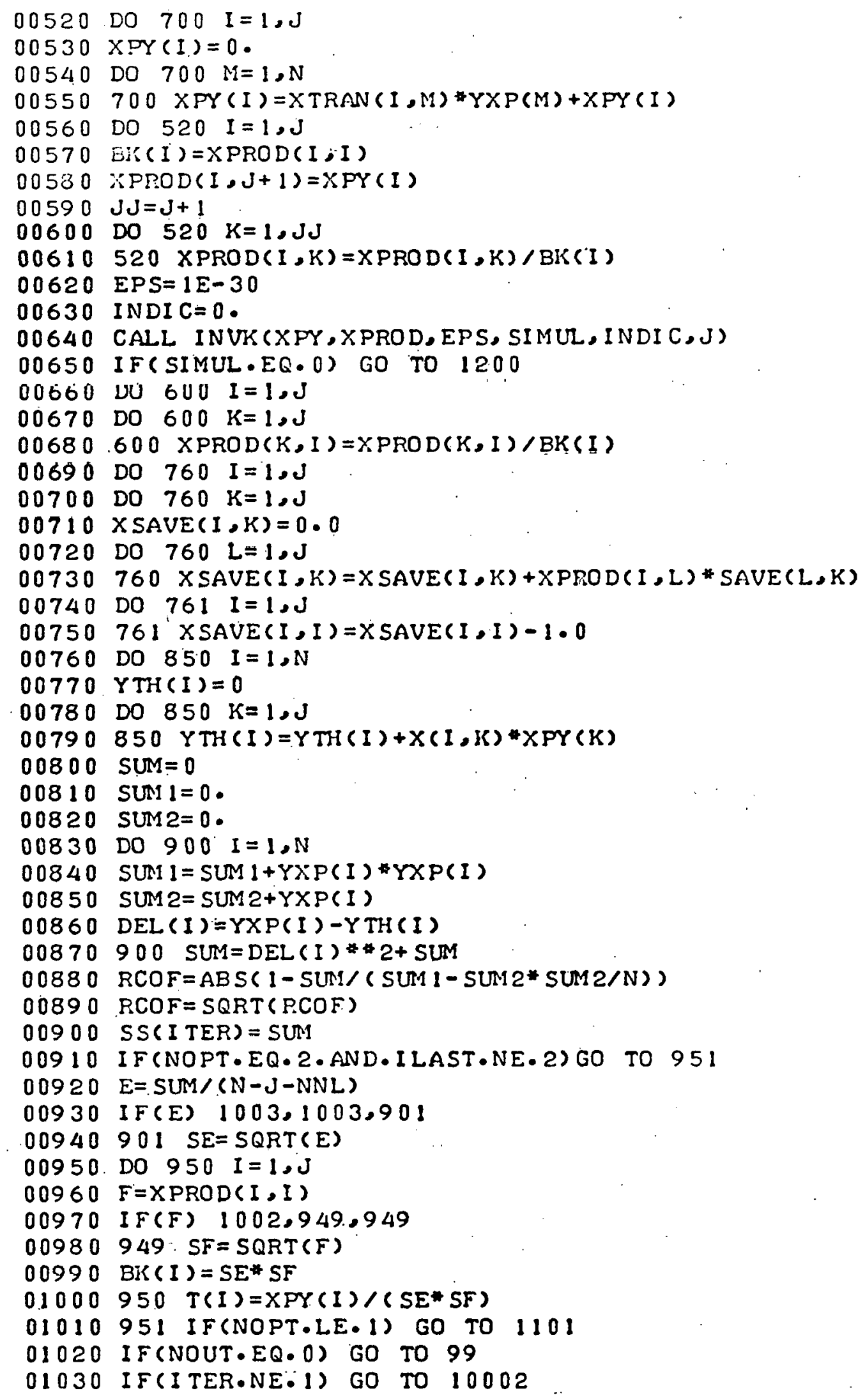




\section{APPENDIX A (continued)}

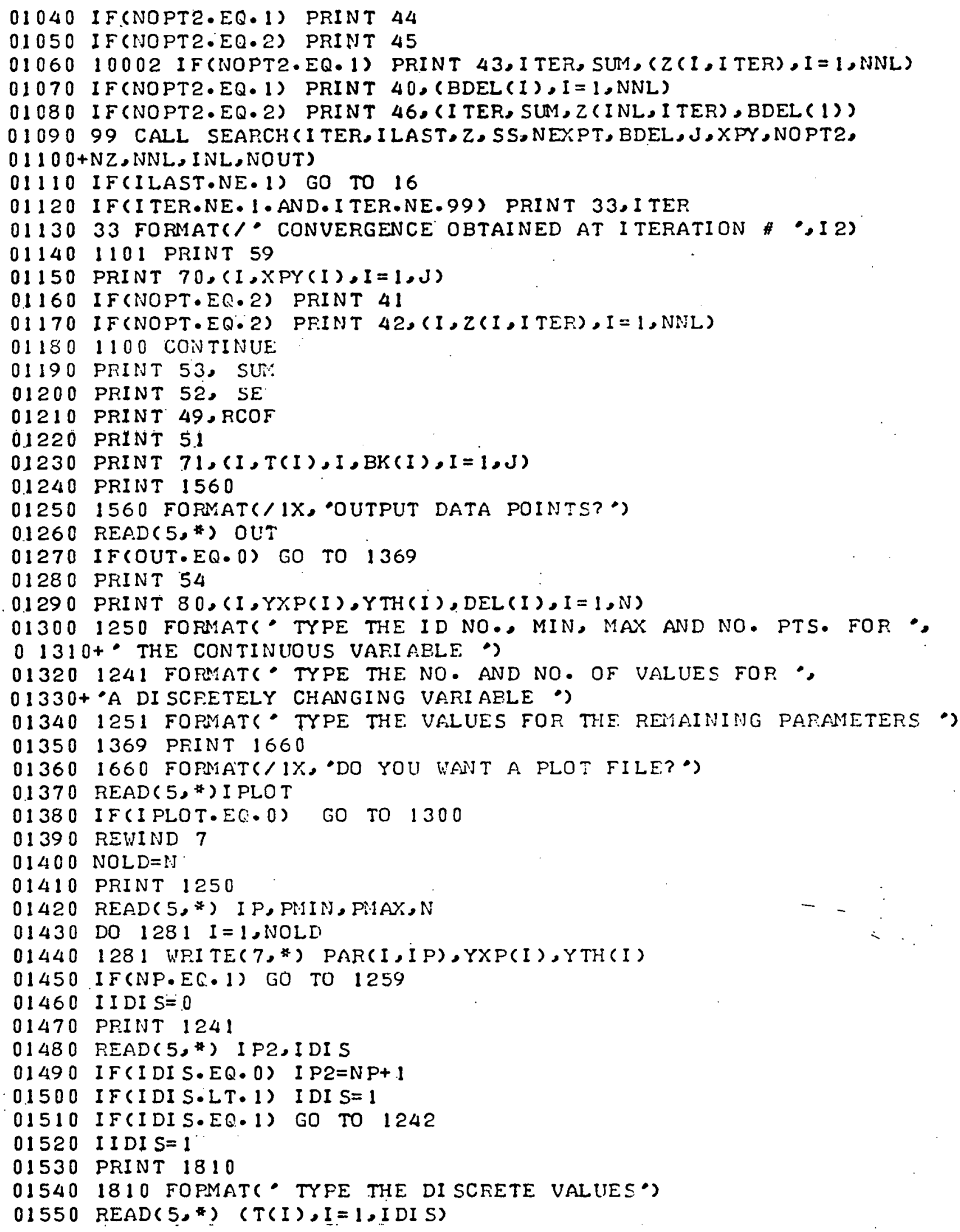




\section{APPENDIX A (continued)}

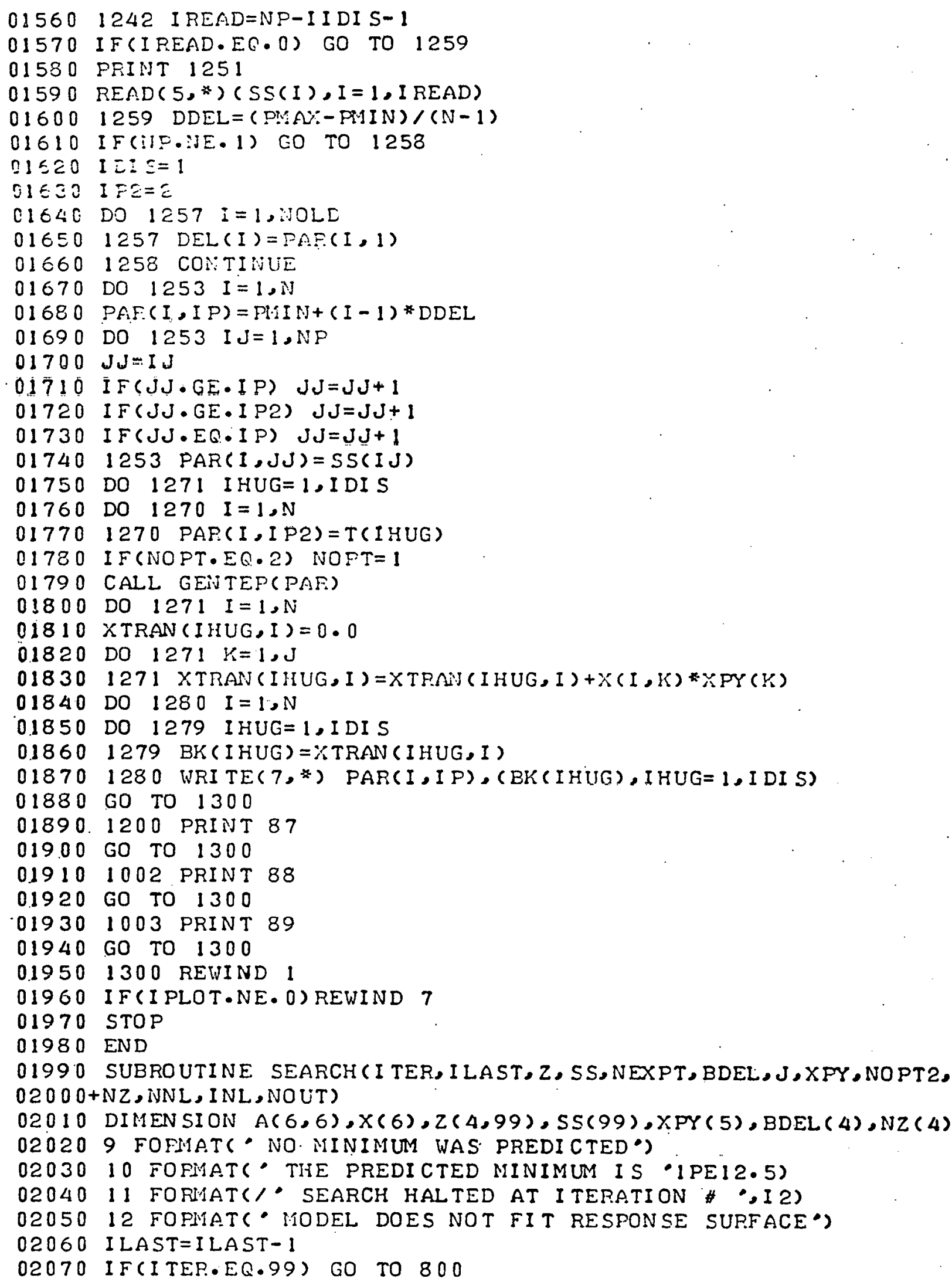




\section{APPENDIX A (continued)}

02080 IF(ILAST.E.Q.1) GO TO 920

02090 GO TO $(5,6)$, NOPT2

$02100 \quad 5 \mathrm{NC}=0$

02110 DO $8 \quad I=1, \mathrm{NNL}$

$02120 \mathrm{~K}=\mathrm{J}-(\mathrm{NNL}-1)$

$02130 \operatorname{BDEL}(I)=X P Y(K) / X P Y(N Z(I))$

02140 DENOM $=Z(1, I$ TEF. $)$

02150 IF $(Z(I, I T E R) \cdot E Q \cdot 0) \quad D E N O M=1 E-20$

02160 DENOM2=DENOM

02170 IF (DENOM.EQ-1.E-20) DENOM2=BDEL (I)

02180 IF (ABS(BDEL(I)/DENOM) . GT. . 1)BDEL (I) =.1*BDEL(I) *

$02190+A B S(D E N O M 2 / B D E L(I))$

$02200 Z(I, I T E R+1)=Z(I, I T E R)+B D E L(I)$

$02210 \mathrm{ADEL}=\mathrm{ABS}(\mathrm{BDEL}(1) / Z(I, I T E R+1))$

022208 IF (ADEL.LT・1 EE-05) NC=NC+ I

$02230^{\circ}$ I TER=I TER+ 1

02240 IF (NC.GE.NNL) GO TO 7

02250 RETURN

022607 ILAST $=2$

$02270 \mathrm{~J}=\mathrm{J}-\mathrm{NNL}$

02280 RETURN

022906 IF (ITER.EQ. 1.AND.BDEL(1).EQ.0) GO TO 800

02300 IF (NEXPT.EQ.4) GO TO 710

02310 IF (NEXPT) $400,50.100$

$02320100.1 F(N E X P T \cdot E Q .2) \quad F U N=1$

02330 IF (NEXPT.EQ.1) FUN=-2

$02340 Z(I N L, I T E R+1)=Z(I N L$, I TER) +FUN*BDEL (1)

02350 INEXPT $=$ NEXPT -1

02360 GO TO 900

$0237050 \mathrm{NCP}=\mathrm{ITER}-3$

02380 DO $80 \quad I=1,3$

$02390 A(I, 4)=S S(N C P+I)$

$02400 A(I, 1)=1$.

$02410 A(I, 2)=Z(I N L, N C P+I)$

$0242080 \quad A(I, 3)=Z(I N L, N C P+I) * 2$

02430 INDI $C=1$

02440 EPS $=1 \cdot E-20$

02450 CALL INUK (X, A,EPS, SINUL, INDIC,3)

02460 I $F(X(3) \cdot L T \cdot 1 \cdot E-10)$ GO TO 750

02470 AMIN $=-X(2) /(2 . * X(3))$

0248090 IF(NOUT.NE:0) PRINT 10,AIIIN

02490 DELi $=Z(I N L, N C P+1)-A H I N$

02500 ADELM=ABS(DELM)

$02510 \quad A D E L=A B S(B D E L(1))$

02520 IF (2*ADEL-ADELM $200,300,300$

$02530200 \mathrm{BDEL}(1)=-(D E L M / A D E L M) * A D E L$

$02540 Z(I N L, I T E R+1)=Z(I N L, N C P+1)+2$ BDEL (1)

02550 GO TO 890

$02560300 \quad Z(I N L, I T E R+1)=A M I N$

02570 ADELM=ADELH/ABS (AMIN)

02580 ADEL=ADEL/ABS (AMIN)

02590 IF (ADELM - LT - 5E-04.AND.ADEL.LT.IE-03) ILAST=2 
RFP-2849

APPENDIX A (continued)

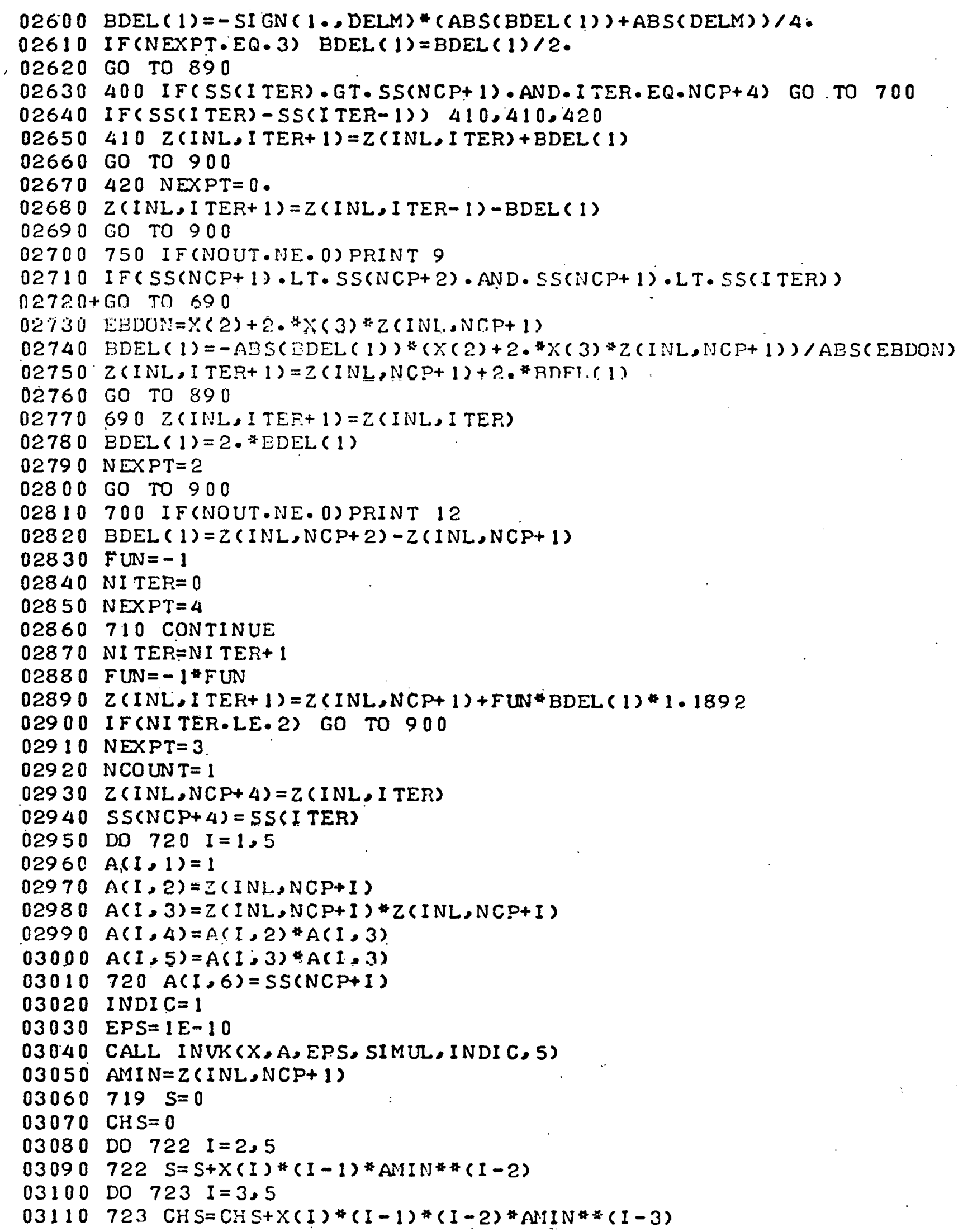


APPENDIX A (continued)

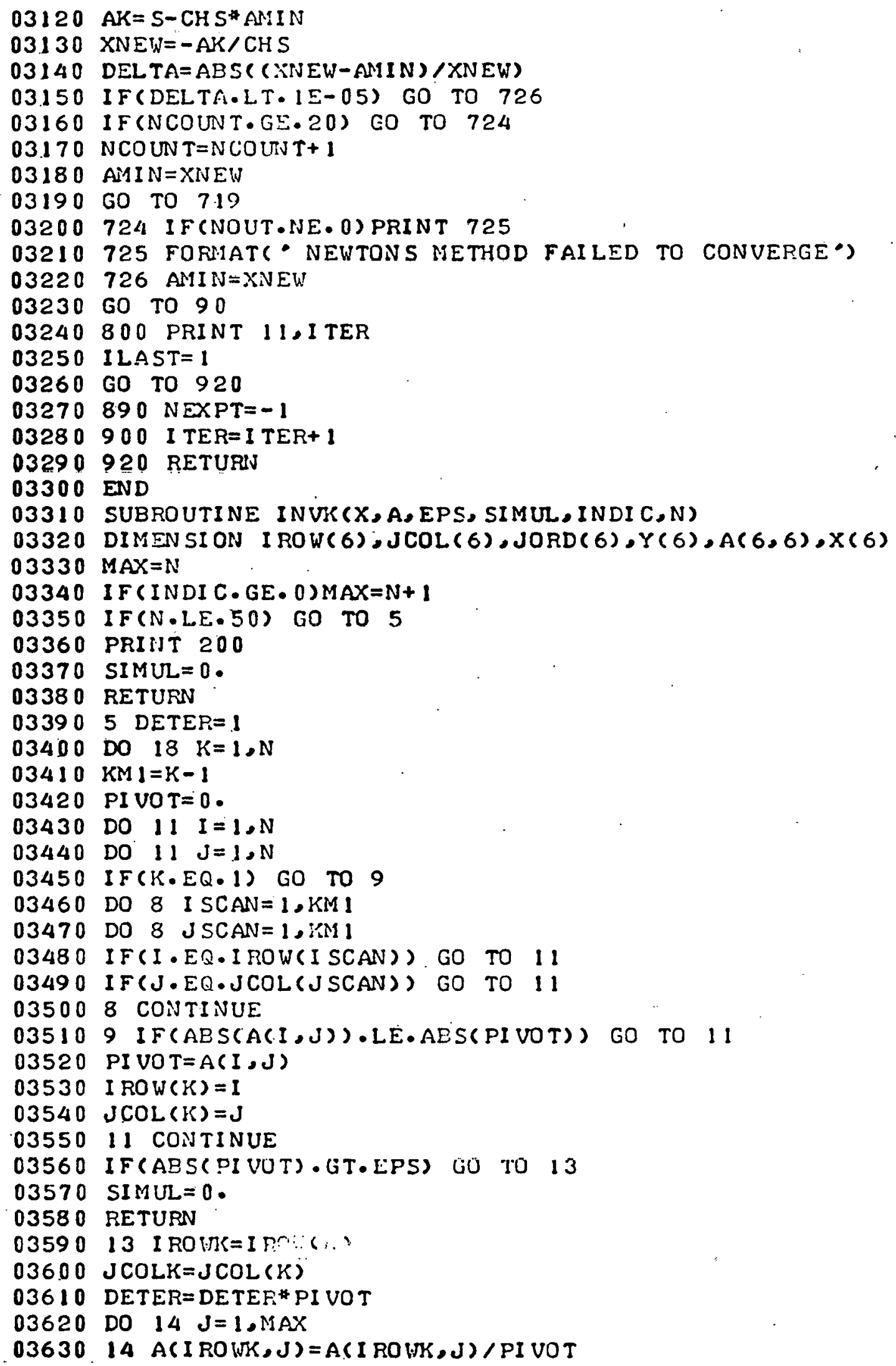


RFP-2849.

APPENDIX A (continued)

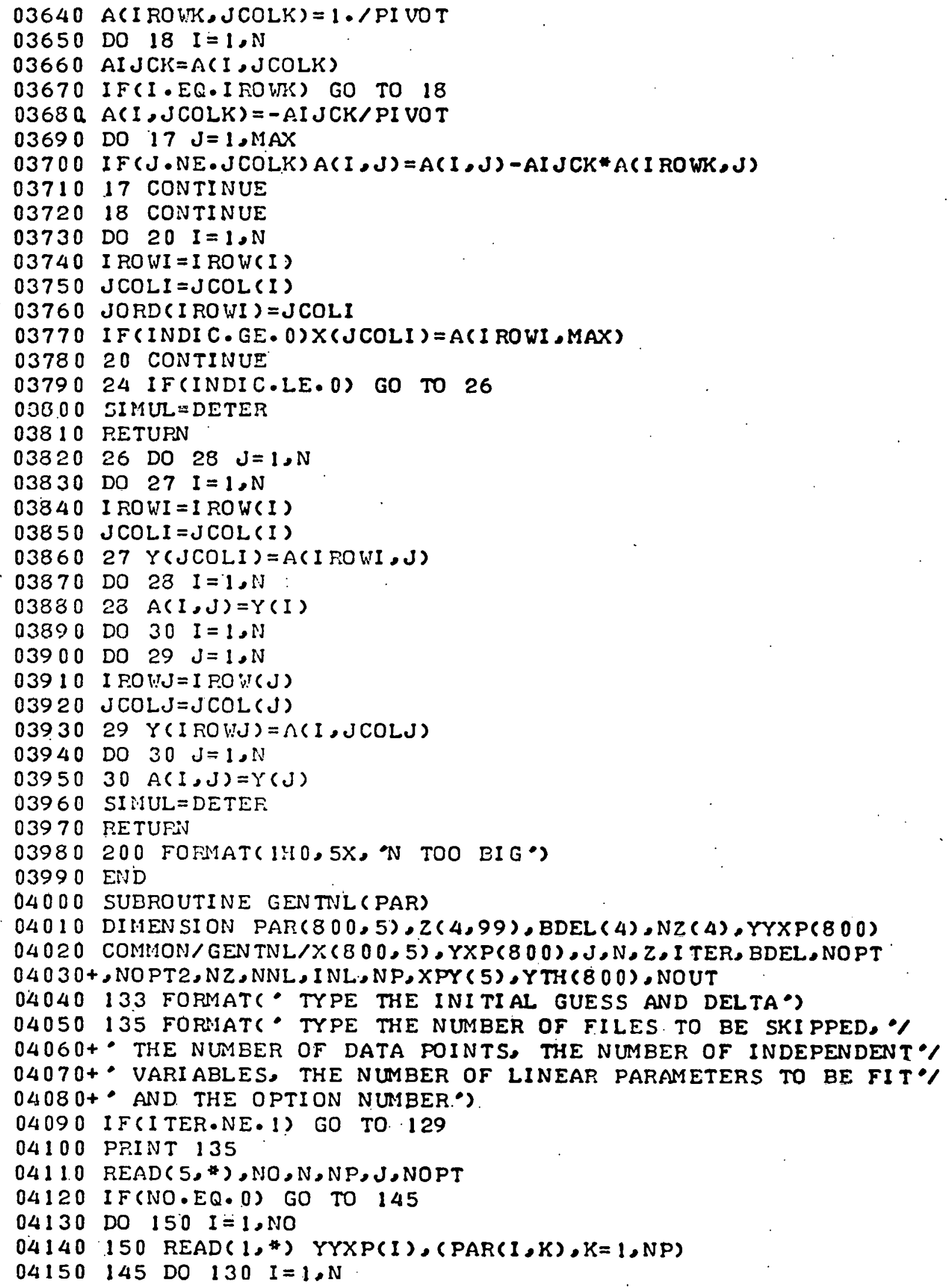




\section{APPENDIX A (continued)}

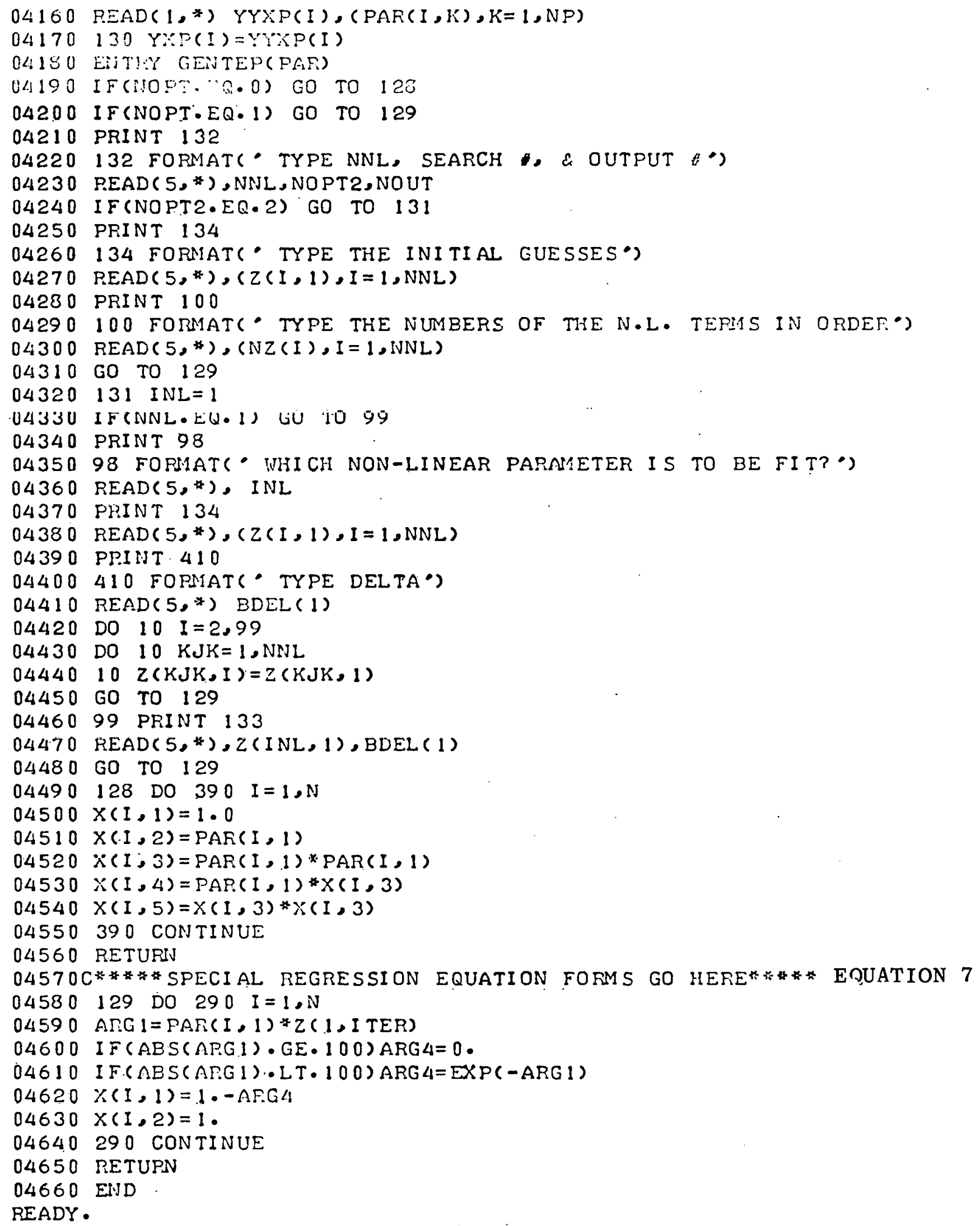


RFP-2849

\section{APPENDIX A (concluded)}

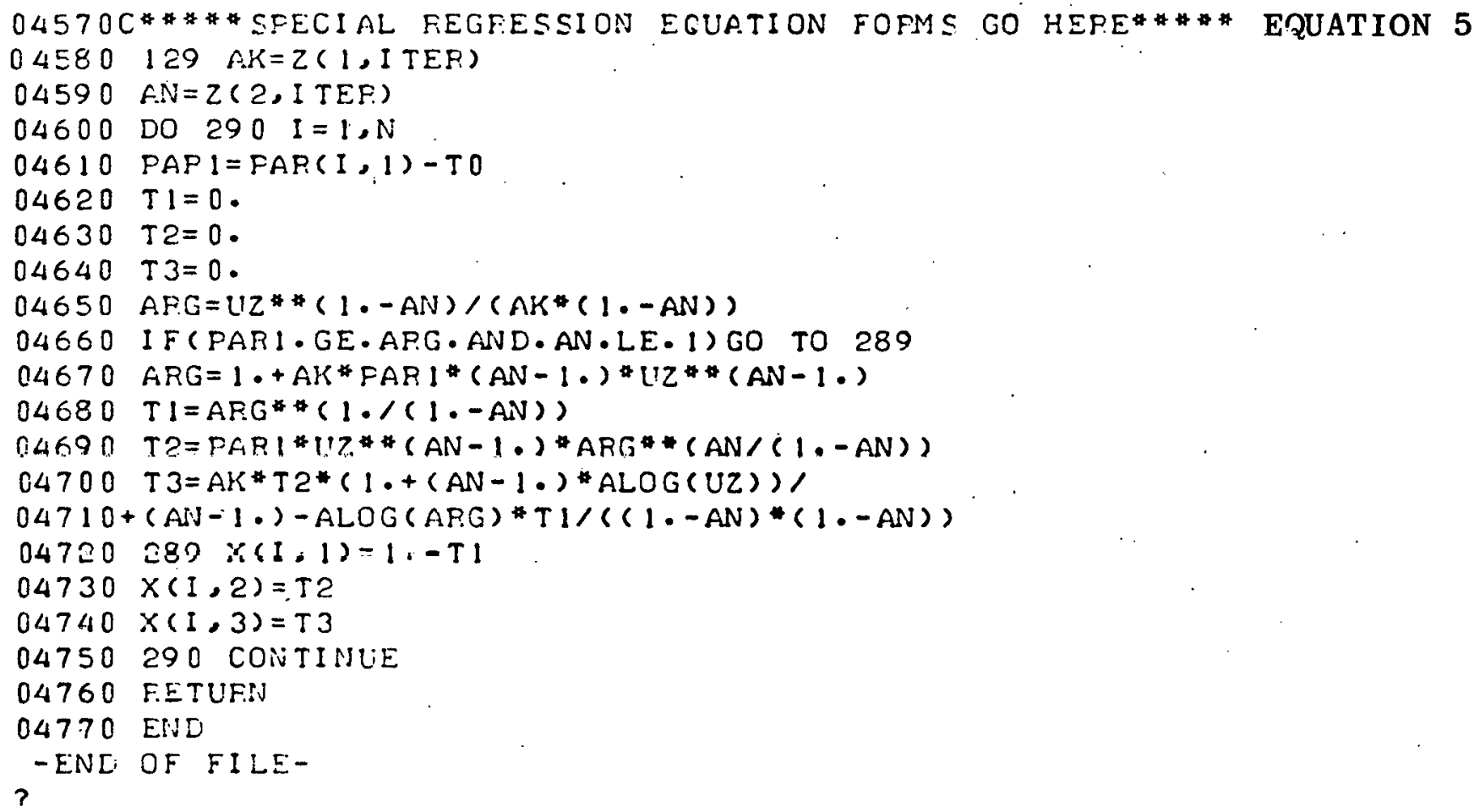




\section{APPENDIX B}

Computer Program for the Jander Equation (Equation 13)

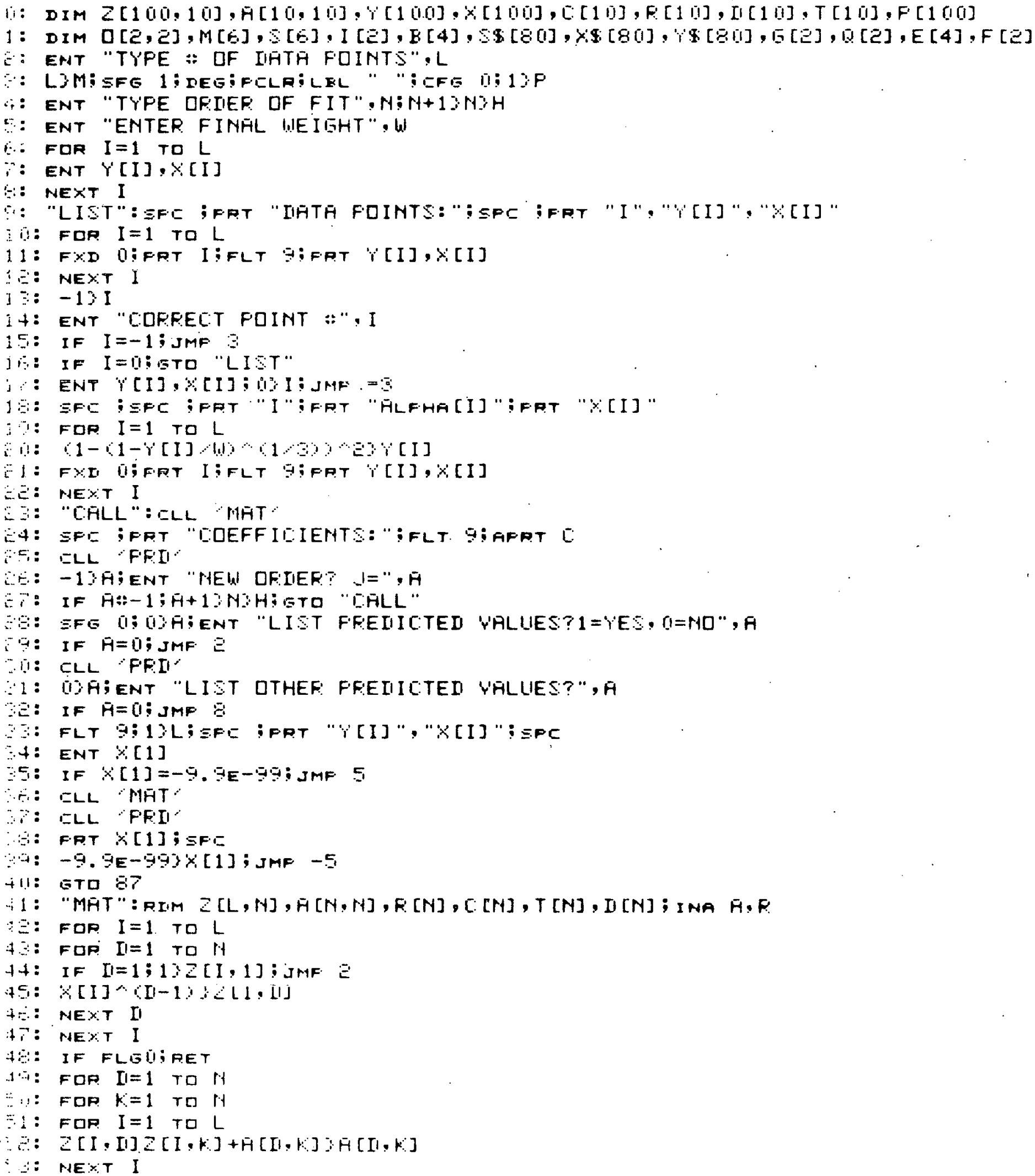




\section{APPENDIX B (concluded)}

H: HEXT K

$\because:$ NEXT II

ED: INU HOA

S: FQR $I=1$ TO $H$

E: FaR $I=1$ TO $L$

5: $Z[I,[I] Y[I]+F:[I] J$ F:[II]

B): NEXT I

1: NEXT II

$\therefore:$ MAT $\mathrm{A} \rightarrow \mathrm{RIC}$

: RET

3 : FFII":0YRSOT

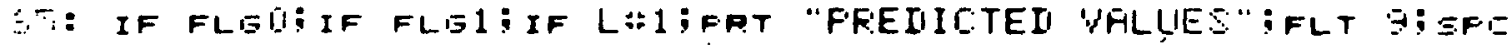

SE: FQP $I=1$ TO $L$

$\because-0, P[I]$

: FRP $\overline{I=1}$ TO 11

$\exists: Z[I, I][[I]+F[I] \geq F[I]$

FI: HEXT II

'1: IF FLDOIIF FLBI;FRT F[I]; JMP 1

$P: Y[I]-F[I]) Z+S Y S: Y[I]+T) T ; Y[I] Y[I]+R\} R$

$\because$ : NEXT I

7: IF FLEQTERT

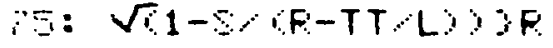

OE FLT BRFAT "SO=",S

$\because: \sqrt{2 S}(L-N)>3 S$

$\dddot{\because} \because$ : FRT "SE=", SFXI TipRT "R =",R

PG: FOR I=1 TO $M$

:U: IF $A[I, I]$ OIPRT "SIMEULLR: ": PEEP

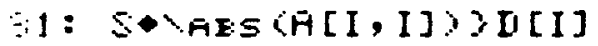

E: C $[\mathrm{I}], \mathrm{II}[\mathrm{I}] \geqslant \mathrm{T}[\mathrm{I}]$

G: NEXT I

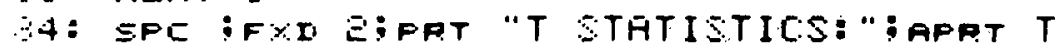

: FLT Z:FRT "IIELTAS: " : AFRT II.

OSUI:GWIRET 


\section{APPENDIX C \\ Computer Program for the Phase Boundary Model (Equation 16)}

II: DIM Z[100,10], $A[10,10], Y[100], x[100], C[10], P[10], I 1[10], T[10], F[100]$

1: DIM $D[2,2], M[6], S[6], I[2], B[4], S \$[80], X S[80], \gamma \$[80], G[2], 0[2], E[4], F[2]$

E: ENT "TYPE : DF IIHTA PDINTS",L

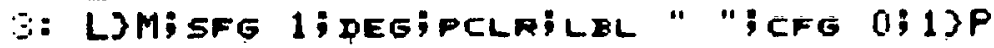

4: ENT "TYPE DRDER DF FIT", N;N+13N3H

5: ENT "ENTER FINAL WEIGHT", $W$

E: FRR I=1 TR L

T: ENT Y[I],X[I]

Q: NEXT I

9: "LIST":SPC ;PRT "DATA PDINTS:";SPC ;PRT "I", "i[I]", "X[I]"

10: FUR $I=1$ TD $L$

11: FXD 0;FRT IBFLT GipRT. $Y[I], X[I]$

12: NEXT I

13: -131

14: ENT "CORRECT PDINT :", I

15: IF I $=-1$; JMP 3

15: IF I=0;BTD "LIST"

17: ENT Y[I],X[I];

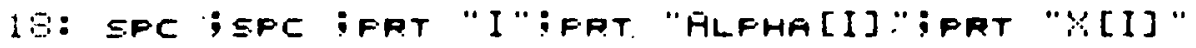

i: FOR $I=1$ TQ $L$

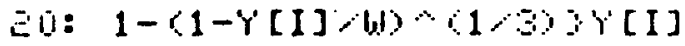

E: FXD DiFRT IBFLT GiFRT Y[I];XII]

E: NEXT I

Z: "CFLL": CLL MAT"

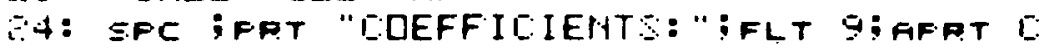

$\therefore C_{1}:$ CLL FFID'

EE: -13ATENT "NEW DFIEET? I=", A

OP: IF FH-1;A+13N3H; STO "IELLL"

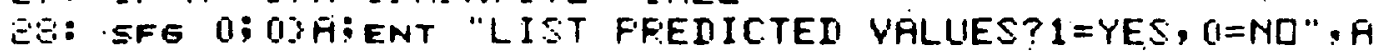

EY: IF $A=0$; JMP $Z$

EI: CLL 'PRD'

1: 0ЗR;ENT "LIST DTHEF FREDICTED VALUES?", R

Z: IF $A=0$; JMP 8

S: FLT 9:13LisPE ;FRT "Y[I]", "X[I]"ispC

I4: ENT $X[1]$

S.: IF $x[1]=-9.9 E-99 ;$ JMP 5

IE: CLL 'MAT'

$\because$ : CLL 'PRI'

YE: PRT X[1]: SPE

$5:-9.9 E-993 \times[1] ;$ JMF -5

41: GTO 87

41: "MAT": PIIM $Z[L, N]: H[N, N], R[N], C[N], T[N], I I[N]$; INA $A, R$

He: FOR $I=1$ TO $L$

4. FOR $\mathrm{D}=1$ TO. $\mathrm{N}$

A: IF $I=1 ; 132[I, 1] ;$ JMF $Z$

d. $: x[I] \wedge(D-1)) Z[I,[1]$

7E: NEXT D

$\rightarrow$ : NEXT I

T: IF FLGOIRET

79: FOR $\mathrm{I}=1$ TO

Si: FOR $K=1$ TO $N$

: : FOR $I=1$ TO $t$

$\vdots: Z Z[I, D] Z[I, K]+F[I, K]: A[I, K]$. 
APPENDIX C (concluded)

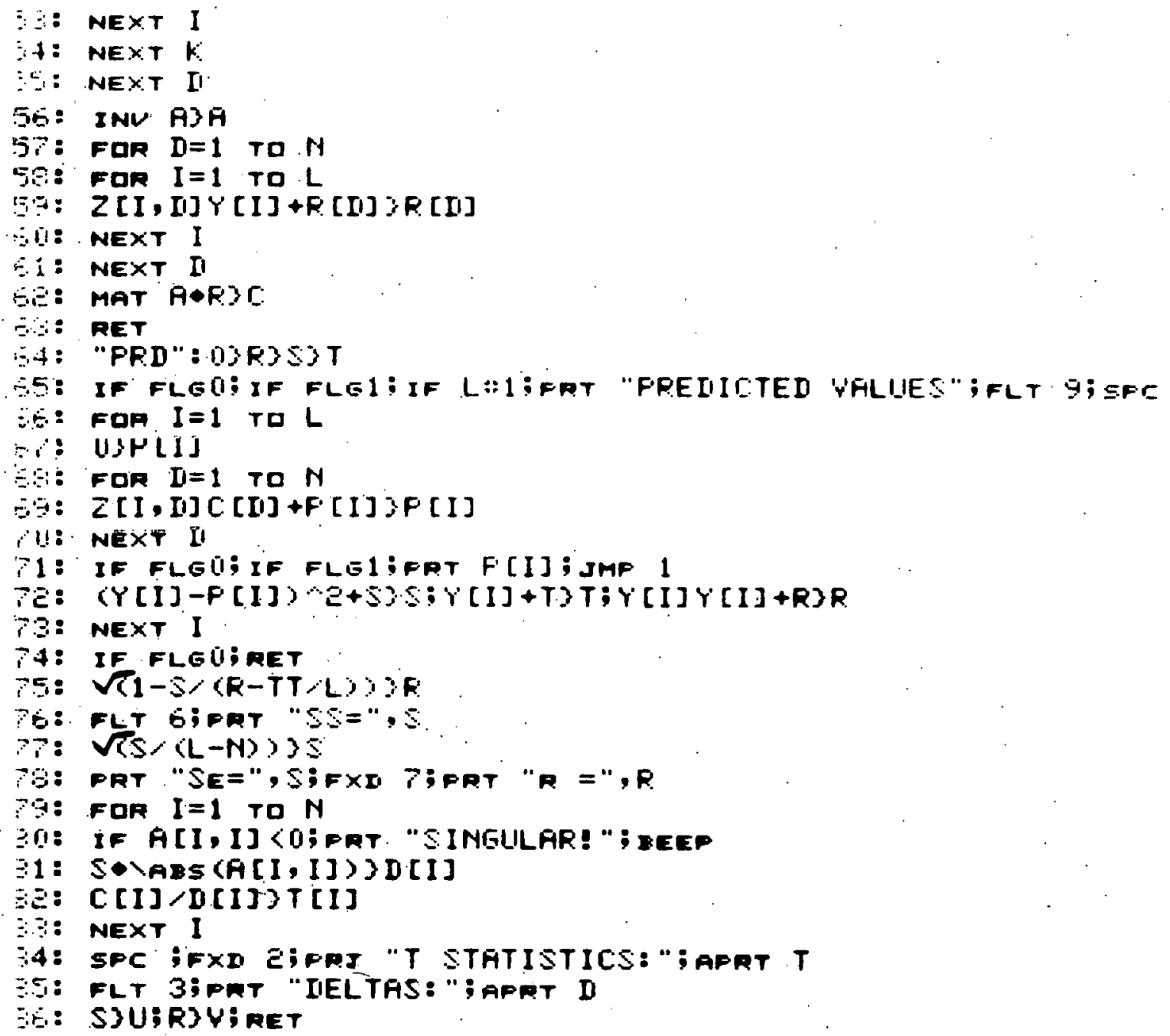

